\title{
Urgences
}

\section{Petit poème...}

\section{Nicole Lavoie}

\section{Numéro 1, 2e trimestre 1981}

URI : https://id.erudit.org/iderudit/025003ar

DOI : https://doi.org/10.7202/025003ar

Aller au sommaire du numéro

\section{Éditeur(s)}

Urgences

\section{ISSN}

0226-9554 (imprimé)

1927-3924 (numérique)

Découvrir la revue

\section{Citer ce document}

Lavoie, N. (1981). Petit poème... Urgences, (1), 14-18.

https://doi.org/10.7202/025003ar d'utilisation que vous pouvez consulter en ligne.

https://apropos.erudit.org/fr/usagers/politique-dutilisation/ 
Nicole Lavoie 
petit poème $d u$ bonheur muet

nous ne parlions pas des mots

mon amour magnifique

nous écoutions simplement le silence

et nous répétions après lui

comme des rimeurs inspirés

petit poème de l'air

moi je rêvais tout haut d'être un oiseau

quand tu chavirais aux cloisons de ma nuit lors même que sombraient les soirs en vertige à l'antenne des plaisirs déicides

petit poème de l'indiscrétion

vous regardez dans la vie des autres

pour voir comment ils sont

et comment vous n'êtes pas 
petit poème de vivre

et l'on vit artistement

parfois comme des funambules

sans nuit sans jour

entre le ber et la bière, la course

les yeux fermés les yeux ouverts un doigt dans l'oeil grinçant des dents les dents dehors plus de dents avec ceci avec cela sans cela sans ceci

? qui vous traverse comme un harpon

une halte dans l'intemporel

une descente aux enfers

une ride à consoler aux fontaines de Jouvence

sous le fard blanc des héros

5,400 degrés Kelvin de lumière

coupe le cou du coq!

monte en haut descends en bas

monte d'en bas descends d'en haut

miroirs à casser

un rêve au sud toi au nord

le paradis à troquer contre les chimères

ses cheveux à compter

c'est après l'infini où ça?

cours va viens

saute rampe couche

une douceur infinie qui n'en finit plus d'être douce

routes parallèles routes croisées

pour un peu pour beaucoup on s'est manqué

et l'avril qui devient incolore

et l'on vit artistement plutôt moine

dedans la jaquette du scientiste 
petit poème de l'imperfection

ou de la douleur de n'être autre

quand j'ai cru te toucher tu n'étais pas palpable tu étais le vent qui tournoie et se dissipe et depuis mes mains battent l'air

quand j'ai cru te deviner tu étais un théâtre où se déroulent tes vies dessous des maquillages et je n'ai rien compris

quand j'ai cru te savoir tu étais un autre avec un autre visage dans une autre vie et je ne t'ai pas reconnu

quand j'ai cru t'aimer tu n'étais pas l'amour mais ce grand oiseau muet prêt à s'envoler et de tant te chercher où faudra-t-il me rendre? 
A Jacinthe

pour la dernière fois assassinée

petite morte d'hier déjà

dans ta robe blanche

à nouveau voilà que tu t'es tue

je voudrais pourtant que s'élèvent des musiques

et puis que retentissent des cris

petite anonyme sans voix sans visage

que n'as-tu gémi le temps d'une plainte qu'on sache ton nom

petite crucifiée au fil des jours

déjà désertée de toi-même

fut-il que tu fus si mal aimée

qu'on ait su te déposséder davantage

petite ensevelie d'une aube pâle

nulle fleur ne sera jetée à ta mémoire

et quel chant porter à mes lèvres

qui dise incessamment combien de fois

combien de mains t'ont assassinée 